\title{
Hans Christoph Buch's Sansibar Blues \\ and the Fascination of Cross-Cultural Experience \\ in Contemporary German Historical Novels about Colonialism
}

Dirk Göttsche (Nottingham)

\begin{abstract}
This article maps four different types of cross-cultural experience in contemporary historical novels about colonial Africa (colonialist, exoticist, intercultural, and transcultural) before focusing on Buch's Sansibar Blues (2008) as a case study in German postcolonial memory and the literary use of transcultural voices. Together with Ilja Trojanow's Der Weltensammler (2006) Sansibar Blues marks a new departure in the history of writing cross-cultural experience and representing the Other, but unlike Trojanow Buch uses partially authentic nonEuropean voices that draw on the autobiographies of two prominent nineteenth-century figures in the linked histories of Zanzibar and Germany, Emily Ruete alias Princess Sayyida Salme of Oman and Zanzibar and ivory dealer Tippu Tip alias Hamed bin Mohammed. The article concludes with a detailed analysis of Buch's adaptation of these sources.
\end{abstract}

In his recent study of the German colonial imagination in Wilhelmine and Weimar literature and film Wolfgang Struck also considers the legacy of colonial phantasies in contemporary German film and television features set in colonial Africa, a highly popular genre during the past ten years. He notes that African characters only play marginal roles in prime-time adventure stories such as Die Wüstenrose (1999) or Afrika, mon amour (2007), ${ }^{1}$ and that the German protagonists of these productions do not experience any meaningful cross-cultural encounters:

Ihre Heldinnen und Helden sind keine Rassisten, sie sind einfach nur zu beschäftigt damit, sich in ihren deutschen Geschichten $\mathrm{zu}$ behaupten, um sich auf andere Geschichten, auf die Geschichten der Anderen einzulassen. Und so müssen Begegnungen nicht mehr abgewertet werden, sie finden einfach nicht statt. An die Stelle rassistischer Apartheit ist schlichtes Desinteresse getreten. ${ }^{2}$

Despite postcolonial correctness in the representation of Africans and due criticism of colonial violence and racism such imaginary constructions of German Heimat in colonial settings effectively re-enact colonial myths of heroism and adventure in exotic terrain. ${ }^{3}$ The

Wolfgang Struck, Die Eroberung der Phantasie: Kolonialismus, Literatur und Film zwischen deutschem Kaiserreich und Weimarer Republik, Göttingen 2010, p. 294.

$2 \quad$ Struck, Die Eroberung der Phantasie, p. 305.

See Struck, Die Eroberung der Phantasie, pp. 283, 288. 
same pattern can also be found in some of the popular historical novels about Africa, which have enjoyed similar success since the late 1990s, particularly in the wake of the centenary of the German colonial war in South-West Africa and the Herero genocide in 2004, which gave unprecedented public prominence to German colonial history. ${ }^{4}$

At the same time, however, cross-cultural experience has arguably been a leitmotif in German historical novels about colonialism since the post-war period, and recent novels by acclaimed authors, such as Ilija Trojanow's Der Weltensammler (2006) and Hans Christoph Buch's Sansibar Blues (2008), ${ }^{5}$ have gone one step further by using transcultural voices to put European colonial narratives in perspective, drawing attention to the cross-cultural experience of the colonized others as well as those Europeans who were willing to open their eyes and minds to the worlds they encountered. After all the European colonial expansion established multifaceted, contested, violent but also sustained cross-cultural contact zones, which ultimately transformed lives, cultures, and societies in both hemispheres, as anti- and postcolonial critics from Albert Memmi and Frantz Fanon to Edward Said and Homi Bhabha have shown. ${ }^{6}$ Contemporary German novels about colonialism in Africa may not do full justice to all aspects of this complex theme, but they do not suggest lack of interest in crosscultural encounters, and the stories of the colonized others are finally also beginning to attract attention. Despite evidence that popular exoticist tropes and colonialist narrative templates are continuing to circulate between literature and film, ${ }^{7}$ there are also significant differences between both media, and novels from Uwe Timm's Morenga (1978) ${ }^{8}$ about Germany's colonial war in South-West Africa to Sansibar Blues about East Africa have given crosscultural experience a prominent place in remembering, reflecting and critiquing German and

See Dirk Göttsche, 'Der neue historische Afrika-Roman: Kolonialismus aus postkolonialer Sicht', German Life and Letters, 56 (2003), 261-280; Dirk Göttsche, 'Rekonstruktion und Remythisierung der kolonialen Welt: Neue historische Romane über den deutschen Kolonialismus in Afrika', in AfrikaDiskurse in der deutschen Literatur und Kultur vom 18. Jahrhundert bis zur Gegenwart, ed. by Michael Hofmann, Amsterdam 2011 (at press); on (post-) colonial memory see Winfried Speitkamp, Deutsche Kolonialgeschichte, Stuttgart 2005, pp. 173-87; Erinnern verhandeln: Kolonialismus im kollektiven Gedächtnis Afrikas und Europas, ed. by Steffi Hobuß and Ulrich Lölke, Münster 2007.

$5 \quad$ Ilja Trojanow, Der Weltensammler, Roman, Munich, $5^{\text {th }}$ ed. 2008 [2006]; Hans Christoph Buch, Sansibar Blues oder Wie ich Livingstone fand, Roman, Frankfurt/M. 2008.

6 See for example Albert Memmi, The Colonizer and the Colonized [1957], transl. Howard Greenfeld, introduced by Jean-Paul Sartre, new introduction by Nadine Gordimer, London 2003; Frantz Fanon, The Wretched of the Earth [1961], preface by Jean-Paul Sartre, transl. Constance Farrington, London 2001; Edward W. Said, Orientalism [1978], London 1995; Homi K. Bhabha, The Location of Culture, London, New York 1994; for introduction see Peter Childs and Patrick Williams, An Introduction to Post-Colonial Theory, Harlow 1997; The Cambridge Companion to Postcolonial Literary Studies, ed. by Neil Lazarus, Cambridge 2004.

7 A prominent example is the recently popular television genre of docufiction, which adapts literary structures and - in this case - mimics colonial narratives, but is now being reimported into narrative, for example, in a pseudo-historical novel about the ,mother' of the colonial novel, Frieda von Bülow; see Monika Czernin, 'Jenes herrliche Gefühl der Freiheit': Frieda von Bülow und die Sehnsucht nach Afrika, Berlin 2008. Also see Struck, pp. 287-88, on this novel. 
European imperialism. ${ }^{9}$ This article will begin by mapping four different types of crosscultural experience in contemporary historical novels about Africa before focusing on Sansibar Blues as a case study in German postcolonial memory and the literary use of transcultural voices.

\section{I.}

One prominent tradition in German cross-cultural literary studies (as opposed to Postcolonial Studies) conceives of cross-cultural encounters primarily in terms of fostering mutual understanding and dialogue designed to overcome prejudice and segregation. ${ }^{10}$ Despite its merits, this ambitious vision, which combines Hermeneutic philosophy with the ethics of multiculturalism, warrants postcolonial critique, since it often fails to acknowledge existing imbalances in power and wealth. ${ }^{11}$ But it has also proved highly productive in German literature, highlighting the relational nature of cross-cultural experience and casting cultural difference, 'Fremdheit',

nicht als Qualität oder Eigenschaft einer jeweiligen anderen Kultur, sondern als ein Interpretament der wechselseitig wahrgenommenen Andersheit. [...] Im Blick auf das Fremde bzw. das Eigene als Fremdes konstituieren sich gleichermaßen das Eigene und das Fremde. ${ }^{12}$

Related ideas of cross-cultural experience as a site of mutual exchange and the construction and transformation of identity through contact, conflict and dialogue also play a crucial role in historical novels about Africa, typically set against colonial power structures and acting as a means of exposing colonial violence and racist thought from intrinsically contemporary perspectives. 'Interkulturalität' thus remains a relevant concept although Wolfgang Welsch amongst others has rejected it along with 'multiculturalism' as separatist and essentialist,

8

Uwe Timm, Morenga, Roman, Cologne 1985.

See Dirk Göttsche, 'Colonialism and National Socialism: Intersecting Memory Discourses in Post-War and Contemporary German Literature', Gegenwartsliteratur: A German Studies Yearbook, 9 (2010), 21742.

See Alois Wierlacher, 'Interkulturelle Germanistik: Zu ihrer Geschichte und Theorie. Mit einer Forschungsbibliographie', in Handbuch Interkulturelle Germanistik, ed. by Alois Wierlacher and Andrea Bogner, Stuttgart 2003, pp. 1-45 (p. 22). For a comparative critique of German 'interkulturelle Germanistik' and 'interkulturelle Literaturwissenschaft' and anglophone Postcolonial Studies see Dirk Göttsche, 'Postkolonialismus als Herausforderung und Chance germanistischer Literaturwissenschaft', in Grenzen der Germanistik: Rephilologisierung oder Erweiterung?, ed. by Walter Erhart, Stuttgart, Weimar 2004 (= Germanistische Symposien, vol. 26), pp. 558-76.

See for example African critics such as Alioune Sow, Germanistik als Entwicklungs-Wissenschaft? Überlegungen zu einer Literaturwissenschaft des Faches "Deutsch als Fremdsprache" in Afrika, Hildesheim 1986; Norbert Ndong, Entwicklung, Interkulturalität und Literatur: Überlegungen zu einer afrikanischen Germanistik als interkultureller Literaturwissenschaft, München 1993.

Corinna Albrecht, 'Fremdheitsforschung und Fremdheitslehre (Xenologie)', in Handbuch interkulturelle Germanistik, pp. 541-547 (pp. 541-42). 
arguing that in the contemporary world cultures can no longer be construed as 'homogen and wohlabgegrenzt'; they have become 'transcultural' by definition due to internal differentiation, global interaction, and hybridisation. ${ }^{13}$ If we leave the politics of theory aside, such criticism epitomizes the shift from intercultural to transcultural debate which throws the cross-cultural dynamic of the colonial world into sharper relief, enabling us to distinguish more clearly between narrative discourses that build on the experience of cultural difference to consider African and European cultures (and the characters representing them) in comparative perspectives, and others that focus on cultural hybridisation and potentially subversive transgressions of the racial divide in the world of colonial imperialism. One of the reasons for contemporary authors' fascination with cross-cultural experience in colonial Africa is clearly the resonance of this theme with contemporary multiculturalism and the increasing significance of transcultural lives in a world of global mobility and migration. But this new awareness of transcultural processes also raises the question of how the colonial world and its discourses of cultural difference can meaningfully be remembered and imagined from contemporary postcolonial perspectives, and how literary narrative can reconcile historical truth with contemporary concerns.

Textual evidence suggests that there are essentially four different types of writing cross-cultural experience in the two dozen and more contemporary historical novels about Africa which have been published since the mid-1990s. ${ }^{14}$ These are not so much distinct discourses than flexible options in a field of choices, and individual novels may pitch different types of cross-cultural interaction against one another. The first type, the colonial model of blind encounters and racial segregation, rules out any cross-cultural exchange and dialogue. It features in most historical novels about colonial Africa as part of historical scene-setting, such as in Timm's Morenga or Alex Capus's Eine Frage der Zeit (2007), ${ }^{15}$ where German colonial officers and their inability and unwillingness to respect Africans as equals or communicate with them exposes 'die Absurdität der kolonialen Welt', as Capus calls it. ${ }^{16}$ Typically associated with minor characters, this colonial model of failing cross-cultural experience

13 Wolfgang Welsch, 'Transkulturalität: Zur veränderten Verfassung heutiger Kulturen', in Hybridkulturen: Medien, Netze, Künste, ed. by Irmela Schneider and Christian W. Thomsen, Cologne 1997, pp. 67-90 (pp.70-72); also see Hendrik Blumentrath, Julia Bodenburg, Roger Hillman, Martina Wagner-Egelhaaf, Transkulturalität: Türkisch-deutsche Konstellationen in Literatur und Film, Münster 2007, pp. 53-57.

14 For an overview see my articles listed in note 4 above.

15 Alex Capus, Eine Frage der Zeit, Roman, Munich 2007; see Göttsche, 'Rekonstruktion und Remythisierung der kolonialen Welt'.

16 Alex Capus in an interview with Beate Arabin on 14.6.2008, http://www.alexcapus.de/interview3.html (21.8.2008). 
moves centre-stage in Gerhard Seyfried's Herero (2003), ${ }^{17}$ where mimicry of the colonial mind-set and language leaves critical detachment to the reader, although Seyfried also follows established literary convention in contrasting hard-core colonialist attitudes with more moderate positions and an imaginary African counter-perspective. The opposite strategy, a critical focus on the colonialist denial of cross-cultural experience, can be seen in Thomas von Steinaecker's Schutzgebiet (2009), which presents the marginalisation of the indigenous West African population as one of the symptoms of the German colonizers' madness ('Die Verrückten'), ${ }^{18}$ and in Thomas Stangl's novel about the 'discovery' of Timbuktu, Der einzige Orte (2004), ${ }^{19}$ which radically deconstructs the 'imperial gaze' (Pratt). ${ }^{20}$ Although entirely dependent on African support Stangl's explorers Gordon Laing and René Caillé remain oblivious of the cultural spaces through which they move and cynical in their dealings with Africans, although Caillé appears of symbolize European cross-cultural experience, camouflaging as a North-African Muslim in a travesty of 'going native'. Paying with their life (Laing) and their health and sanity (Caillé) respectively, they provide graphic illustration of the missed opportunities for a different history of European-African encounters, and Stangl complements his highly self-reflexive deconstruction of colonial narratives of exploration by also including elements of an African counter-narrative. Despite a very different narrative structure, Der einzige Ort thus anticipates Trojanow's and Buch's novels in theme and postcolonial perspective.

The second and dominant model of cross-cultural experience in historical novels about Africa, however, draws on the Bildungsroman tradition of personal development through social experience. ${ }^{21}$ It foregrounds cross-cultural learning processes of European protagonists, whose growing disenchantment with the colonial system and mindset, and increasing interest in the Africans around them, enables novelists to reconcile historical representation with postcolonial critique. Timm set an influential precedent for this type of narrative with the fictional protagonist of Morenga, a veterinary surgeon who soon comes to question the colonial war, befriends the local Nama, embarks on a relationship with an African woman, and slips into a form of passive resistance that is derided by his army peers as

\footnotetext{
17 Gerhard Seyfried, Herero, Roman, Frankfurt/M. 2003; see Stefan Hermes, 'Fahrten nach Südwest': Die Kolonialkriege gegen die Herero und Nama in der deutschen Literatur (1904-2004), pp. 219-47.

18 Thomas von Steinaecker, Schutzgebiet, Roman, Frankfurt/M. 2009, p. 9.

19 Thomas Stangl, Der einzige Ort, Roman, Vienna 2004; see Michaela Holdenried, 'Passagen ins kulturelle Anderswo imaginärer Geographie: Thomas Stangls Timbuktu-Roman "Der einzige Ort"', in Akten des XI. Internationalen Germanistentages in Paris 2005, vol, 9, ed. by Jean-Marie Valentin et al., Bern, Berlin 2007, pp. 153-60.

$20 \quad$ See Mary Pratt, Imperial Eyes: Travel Writing and Transculturaltion, $2^{\text {nd }}$ ed. London 2008.

21 For introduction see Rolf Selbmann, Der deutsche Bildungsroman, Stuttgart 1984
} 
'Verkafferung'. ${ }^{22}$ Hermann Schulz takes this model of cross-cultural experience as a site of intercultural education to an almost didactic level in his novel Auf dem Strom (1998), ${ }^{23}$ whose protagonist, a German missionary in 1930s Tanzania, encounters a range of African individuals and cultures on a boat trip down a river, meant to save his daughter from serious illness. This journey is cast as an intercultural Bildungsreise, which raises awareness and appreciation of African heritage, knowledge and humanity in a world that defies European colonial rule. Auf dem Strom includes instances of cultural hybridisation in both German and African characters, also providing at least snapshots of African cross-cultural experience under colonial conditions. Similar mirroring of cross-cultural experience in European as well as African characters can be found in Jens Johannes Kramer's novel Die Stadt unter den Steinen (2000). Its protagonist, another German missionary, and his West African counterpart, whose life epitomizes cultural hybridisation in colonial Africa, both cross the racial and cultural divide in search of the mythical city of the novel's title, where 'Schwarze und Weiße, Heiden und Christen von gleich zu gleich miteinander umgehen' ${ }^{24}$

While Kramer's and Schulz's novels embrace the postcolonial objective of 'the rereading and the rewriting' of colonialism ${ }^{25}$ and challenge Eurocentric historiography, others inform their protagonists' cross-cultural experiences with visions of intercultural dialogue despite colonial conditions. Ilona Maria Hilliges's Sterne über Afrika (2007), ${ }^{26}$ for example, takes the cross-cultural learning process of its protagonist, a young female German doctor, to the point of medical partnership with a traditional African healer, based on mutual respect and shared knowledge, and her brother equally defies colonial ideology by seeking to establish German-African partnership on his East African farm. The problem with this intercultural vision is that it tailors cross-cultural experience to European mentorship in African development and also reintroduces exoticist tropes of African magic and adventure. The exoticist model of cross-cultural experience, however, the third of the four discussed here, unwittingly reinforces the colonialist grounding of cultural difference in race and perpetuates traditional notions of European cultural superiority by stereotypically casting Africans as the

\footnotetext{
22 Timm, Morenga, p. 151; for recent research see Hermes 'Fahrten nach Südwest', pp. 178-202; Martin Hielscher, Uwe Timm, Munich 2007, pp. 82-94. Hermann Schulz, Auf dem Strom, Roman, Hamburg 1998; see Göttsche 'Der neue historische AfrikaRoman', pp. 272-75.

24 Jens Johannes Kramer, Die Stadt unter den Steinen, Munich 2000, p. 473; see Göttsche, 'Der neue historische Afrika-Roman', pp. 269-72.

25 Bill Ashcroft, Gareth Griffiths, Helen Tiffin, The Empire Writes Back: Theory and Practice in PostColonial Literatures, London, New York, $2^{\text {nd }}$ edition 2002, p. 221.

26 Ilona Maria Hilliges, Sterne über Afrika, Roman, Reinbek bei Hamburg 2007; see Göttsche, 'Rekonstruktion und Remythisierung der kolonialen Welt'.
} 
(natural, emotional, unspoilt or violent, irrational, sexualised, childlike, etc.) other. ${ }^{27}$ Ray Müller's Ein Traum von Afrika (2007) and Rolf Ackermann's Die weiße Jägerin (2005), ${ }^{28}$ both set in East Africa, provide further evidence of the persistence of exoticist discourse and the return of colonialist narratives, although they also use their protagonists' cross-cultural experience and partnership with Africans to criticise aspects of the colonial system. Novels such as these support Wolfgang Struck's analysis that the current popularity of the colonial theme is marked by disconcerting re-enactments of colonial life and thought. ${ }^{29}$

Keen to break with traditional European stereotypes about Africa and Africans, with racist othering and exoticist projection, novelists such as Timm, Kramer and Capus have been cautious in their use of African characters, aware of the danger of appropriation even where the intention is to give the African experience a voice. Novels such as Ackermann's Die weiße Jägerin, which uses a mythical African voice to cross-stitch the history of German colonial settlement in Tanzania with the history of African liberation, only serve to reinforce scepticism against exoticist imaginations of African experience. The only recent exception is Giselher W. Hoffmann's Die schweigenden Feuer (1994), ${ }^{30}$ a fictionalized account of Herero history from 1861 to 1905 by a German-Namibian author, who focuses entirely on the African experience of colonial encounters and on the impact of German colonialism on African history. Earlier examples of similarly extensive literary engagement with African crosscultural experience are restricted to East German writers, who drew on Marxist universalism and Leninist anti-imperialism to move freely between European and African characters and perspectives, casting African rebellion against German colonial rule as anticipation of later successful liberation wars. In GDR novels such as Ferdinand May's Sturm über SüdwestAfrika (1962) or Dietmar Beetz's Flucht vom Waterberg (1989) $)^{31}$ African cross-cultural experience plays a crucial role in the literary critique of German colonialism, and Beetz, in

27 See Dirk Göttsche, 'Zwischen Exotismus und Postkolonialismus: Der Afrika-Diskurs in der deutschsprachigen Gegenwartsliteratur', in Interkulturelle Texturen: Afrika und Deutschland im Reflexionsmedium der Literatur, ed. by M. Moustapha Diallo and Dirk Göttsche, Bielefeld 2003, pp. 161244 (pp. 166-68); Die andere Welt: Studien zum Exotismus, ed. by Thomas Koebner and Gerhart Pickerodt, Frankfurt/M. 1987; Noah Sow, Deutschland Schwarz Weiß: Der alltägliche Rassismus, Munich 2008, pp. 217-20; Afrika und die deutsche Sprache: Ein kritisches Nachschlagewerk, ed. by Susan Arndt and Antje Hornscheid, Münster, $2^{\text {nd }}$ ed. 2009.

28 Ray Müller, Ein Traum von Afrika, Roman, Munich 2007; Rolf Ackermann, Die weiße Jägerin, Roman, Munich 2005; see Göttsche, 'Rekonstruktion und Remythisierung der kolonialen Welt'.

$29 \quad$ Struck, Die Eroberung der Phantasie, p. 298.

30 Giselher W. Hoffmann, Die schweigenden Feuer: Roman der Herero, Wuppertal 1994; see Bruno ArichGerz, 'Postkoloniale Prosaliteratur zwischen Einfühlungs- und Rezeptionsästhetik: Zur (Erzähl-) Perspektive "der Anderen" bei Gerhard Seyfried, Dietmar Beetz und in Giselher W. Hoffmanns Die schweigenden Feuer (1994)', Acta Germanica: German Studies in Africa, 37 (2009), 33-44.

31 Ferdinand May, Sturm über Südwest-Afrika, Berlin 1962; Dietmar Beetz, Flucht vom Waterberg, Roman, Berlin 1989; see Hermes, pp. 159-178, 202-217; Göttsche, 'Colonialism and National Socialism', pp. 221-23. 
particular, deliberately focuses on Africans in German service and repeated border-crossing between the warring factions to explore the intersections between racial and class tensions. The ideological framework underpinning these novels collapsed with the demise of GDR, and extensive engagement with the African experience has since become rare, except in literature for children and adolescents. ${ }^{32}$

Trojanow's Der Weltensammler and Buch's Sansibar Blues therefore mark a new departure in the representation of cross-cultural experience in colonial space. They develop new modes of voicing the other in a fourth and final type of cross-cultural narrative. Both make cross-cultural experience a prominent theme and extend German literary engagement with colonialism through transcultural multiperspectivism, which interrelates European and non-European narratives. In all of its three parts, set in India, Arabia and East Africa respectively, Trojanow's Weltensammler alternates between a narrative that follows British colonial officer Richard Burton's cross-cultural adventures and journeys of exploration from his perspective, often using internal focalisation, and counter-strands which aim to represent indigenous perspectives and the experience of the colonized. And these 'contrapuntal' nonEuropean voices again branch out into 'innere Pluralität und Vielschichtigkeit', ${ }^{33}$ defying expectations of one homogeneous or authentic other, since the representatives of those other cultures discuss the British protagonist's penetration of their world in different ways. This transcultural multiperspectivism also allows for meta-reflexive critique of the novel's poetics and, certainly in the Indian and East African parts, introduces a memory theme. The novel opens with the protagonist's death and symbolic rebirth from the ashes of his diary, in a modern reference to the ancient myth of Mnemosyne as the muse of poetic inspiration, and the Indian counter-narrative extends this metareflexive memory discourse by letting Burton's servant Ramji Naukaram tell his side of the story to an Indian scribe with literary ambitions. Subheaded 'In der Erinnerung verschwimmt die Schrift', the African chapters continue this theme by framing the African counter-narrative in an oral memory setting: in his old age, Burton's guide Sidi Mubarak Bombay, a liberated East African slave, tells the story of his life to a group of friends, neighbours and children in Zanzibar, who respond to his account of colonial exploration in their own ways, implicitly providing evidence of the particular dynamic of oral history.

Despite this complex transcultural narrative, however, it would appear that Trojanow continues in the established tradition of voicing the other by working with imaginary non-

See Gina Weinkauff, Fremdwahrnehmung: Zur Thematisierung kultureller Alterität in der deutschsprachigen Kinder- und Jugendliteratur seit 1945, Munich 2006. 
European character-narrators. By contrast, Hans Christoph Buch's Sansibar Blues oder: Wie ich Livingstone fand (2008), whose subtitle makes ironic reference to the Zanzibari slave trader Hamed bin Mohammed as much as to Henry Morton Stanley, ${ }^{34}$ draws partially on authentic transcultural voices for different, but equally fascinating multiperspectivist memory of colonial history. Buch's novel echoes Trojanow's in focusing on the cultural triangle between India, Arabia and East Africa and the legacies of its deep history. This emerges as a new theme in historical novels about colonialism, building on established fascination with cross-mapping discourses about Africa and the Orient. ${ }^{35}$ But Sansibar Blues also differs from Der Weltensammler in its focus on the links between Germany and Africa, its historical perspective at the rise and aftermath of colonial imperialism, and the complementary rather than contrapuntal arrangement of narrative strands, as a case study of Sansibar Blues will show in more detail.

II.

Cross-stitching European and African experiences, blending narrative with essayism, and balancing multiperspectivism and kaleidoscopic structure with coherence in theme, discourse and style, Sansibar Blues is in many ways a highly unusual engagement with German colonialism. Using humour and irony to put colonialism and neo-colonialism in critical perspective, the novel alternates between four narrative strands, which combine to cover the history of Zanzibar and its African hinterland as well as German involvement there from the 1850s to the present day, integrating historical assessment in fictionalised biography. The contemporary chapters and the author's epilogue act as a metareflexive framework, which ties the three historical narratives together and links their themes to contemporary postcolonial critique. Casting the novel as 'ein System kommunizierender Röhren' that feeds on colonial documents and travel writing as well as Buch's own experiences in East Africa, the novel's contemporary chapters highlight ' $\mathrm{da}$ und wie die koloniale Vergangenheit in der Gegenwart

\footnotetext{
33 Jana Domdey, 'Interkulturelles Afrikanissimo: Postkoloniale Erzählverfahren im Ostafrika-Kapitel von Ilija Trojanows Der Weltensammler (2006)', Acta Germanica, 37 (2009), 45-66 (52).

34 See Henry Morton Stanley, How I Found Livingstone (1872). Buch casts Tippu Tip very much as an Arabian precursor of colonial exploration and rule.

35 A recent example is Alex Capus, Munzinger Pascha, Roman, Zurich 1997. But the tradition of crossmapping Africa and the Orient goes back to medieval times and has been prominent in the European colonial imagination during the colonial period, see Wilhelm Raabe's novel Abu Telfan oder die Heimkehr vom Mondgebirge (1866), Giuseppe Verdi's opera Aida (1871), Karl May's oriental cycle of novels (1892), August Macke's watercolour paintings of Tunis (1914), or Hugo von Hofmannsthal's Reise im nördlichen Afrika (1925), to name but a few examples. Also see Peter Martin, Schwarze Teufel, edle Mohren: Afrikaner in Bewußtsein und Geschichte der Deutschen, Hamburg 1993; Klaus von Beyme, Die Faszination des Exotischen: Exotismus, Rassismus und Sexismus in der Kunst, Munich 2008.
} 
fortwirkt' (p. 224) ${ }^{36}$ Written in the type of second-person narrative also used in Buch's novel Kain und Abel in Afrika (2001) about the Rwandan genocide and its colonial background, ${ }^{37}$ these chapters also illustrate the continuing impact of colonial history on the popular imagination of Africa. This is reflected in the author-narrator's grotesque dream of a safari adventure (pp. 6-10), in his supposedly vampire-like use of Zanzibar as a fascinating 'Kreuzungspunkt der Kulturen' (p. 10), and in stark motifs of 'Tod und Verwesung' (p. 106), which continue to associate Africa stereotypically with 'apocalyptic' violence, deprivation and war (p. 108). ${ }^{38}$ The epilogue makes Buch's emphasis on disastrous continuities even more explicit, suggesting that postcolonial atrocities, such as those in contemporary Congo, may even justify nostalgia for German colonialism in some of the Africans whom he meets (pp. 224-25). While the novel's three historical strands do not suggest or support such nostalgia, they develop this memory theme further, drawing on the autobiographical mode of retrospective narrative to combine story-telling with critique. The fourth character-narrator explicitly marks the account of his life as resistance against oblivion, 'dem alles nivellierenden Vergessen' (p. 72).

Buch's telescoping of different temporal and historical layers as a reflection on the connections between the colonial past and the present is also supported by his use of intermediality. The actual text is framed by two picture galleries of maps and photographs, with black-and-white prints relating to the colonial period and the narrative strands representing it, and the colour prints oscillating between the iconography of contemporary tourism and a dated modernity that references the novel's second strand, which bridges the gap between the nineteenth century and the present. Photographs of course are a prominent medium of memory, and recent German literature in the wake of W. G. Sebald's influential combinations of text and photography has made particular use of such intermediality as part of transgenerational memory narratives that reflect German history through family history. ${ }^{39}$ Buch's unusually extensive picture gallery in Sansibar Blues applies a variation of this technique to colonial history, approaching the colonial past from a metareflexive memory perspective that overarches the kind of historical reconstruction suggested by the three extracts from colonial sources which conclude the epilogue (Alfred Brehm's Reiseskizzen aus

\footnotetext{
36 Page numbers in the text refer to Hans Christoph Buch, Sansibar Blues oder Wie ich Livingstone fand, Roman, Frankfurt/M. 2008.

37 Hans Christoph Buch, Kain und Abel in Afrika, Roman, Berlin 2001; see Göttsche, 'Der neue historische Afrika-Roman', pp. 278-79.

38 See Afrika und die deutsche Sprache; Harald Pichlhöfer, Typisch Afrika: Über die Interpretation von Afrikabildern: Eine semiotische Studie, Vienna 1999.
} 
Nord-Ost-Afrika, 1855; Hans Meyer's Ostafrikanische Gletscherfahrten, 1890; news coverage of the court case about Carl Peters's colonial atrocities, 1897; pp. 229-241). The novel is characterized throughout by sharp tensions between the use of historical sources and the radical remoulding of historical material from a deliberately subjective contemporary perspective. Its blending of forgotten historical detail and ironic presentation in order to incite contemporary curiosity and challenge established narratives differs significantly from Uwe Timm's related technique of blending montage and fiction in Morenga. Where Timm pioneered German postcolonial memory in the context of post-1968 social critique, Buch's postmodern memory discourse engages ironically with postcolonial and resurgent colonial fascinations.

Moving backwards in time, the second strand of Sansibar Blues gives a retrospective account of the life of an East German diplomat, who faces grotesque political turmoil in newly independent Zanzibar in 1964 only to find out later that he is the illegitimate son of Duke Adolf Friedrich zu Mecklenburg-Schwerin, a former governor of colonial Togo and his childhood mentor. Surprisingly, and in defiance of post-war East Germany's professed antiimperialism, GDR Third World politics thus appear as symbolic extensions of German colonialism.

The colonial period itself is covered in two transcultural narratives, which blend, in an almost surreal way, colonial experience with present-day knowledge and language, often using the autobiographical mode of writing for thinly veiled historical essayism. Emily Ruete, born Princess Sayyida Salme (1844-1924), the daugher of Sultan Said of Oman and Zanzibar, married Rudolf Heinrich Ruete, a merchant from Hamburg, in Aden in 1867, converted to Protestantism, and spent most of her subsequent life in Germany. ${ }^{40}$ In Sansibar Blues her narrative combines the account of her transcultural life with a summary of German colonial politics towards Zanzibar and her use as a pawn in the European 'scramble for Africa', when in 1885, fifteen years after her husband's untimely death in a horse tram accident, she alligned her unsuccessful attempts to reclaim her Zanzibari inheritance with Bismarck's diplomatic and military strategy of forcing Sultan Bargash to accept German rule in mainland East Africa. And in the fourth strand, legendary Zanzibari slave trader and ivory dealer Hamed bin

\footnotetext{
$39 \quad$ See Anne Fuchs, Die Schmerzensspuren der Geschichte: Zur Poetik der Erinnerung in W. G. Sebalds Prosa, Cologne 2004; W. G. Sebald: A Critical Companion, ed. by Jonathan J. Long and Anne Whitehead (Edinburgh 2004).

40 See Julius Waldschmidt, 'Salima bint Said \& Emily Ruete: Ein Frauenleben zwischen Orient und Okzident', in Unbekannte Biographien: Afrikaner im deutschsprachigen Europa vom 18. Jahrhundert bis zum Ende des Zweiten Weltkrieges, ed. by Ulrich van der Heyden, [no place:] Kai Homilius, 2008, pp. 238-245.
} 
Mohammed, better known as Tippu Tipp, ${ }^{41}$ takes the narrative back into the pre-colonial period in a lively account of his adventures in Eastern and Central Africa and his involvement with Henry Morton Stanley's famous expeditions and the retrieval of Eduard Schnitzer alias Emin Pascha, the German governor of Egyptian Soudan. Buch's narrative technique thus defies clear-cut distinctions between historical reconstruction, cross-cultural curiosity and exotic colonial adventure. But it also echoes other recent novels such as Schulz's Auf dem Strom and Capus's Eine Frage der Zeit in refusing to cast Africans as victims. Both transcultural voices are from the Zanzibari elite, and unlike Sidi Mubarak Bombay, his counterpart in Trojanow's Weltensammler, Buch's Tippu Tipp is seen very much as a perpetrator of the slave trade and a facilitator of colonial expansion.

The use of transcultural voices for multiperspectivist memory of colonialism is certainly the novel's most striking feature. Analysis of Buch's use of Ruete's memoirs and letters and brief comparative consideration of his use of sources in the Tippu Tip strand of Sansibar Blues will therefore enable fuller understanding of the novel's poetics of transcultural memory.

The two chapters on German colonialism in East Africa and its domestic contexts, as seen through the life and experiences of Sayyida Salme alias Emily Ruete, draw heavily on her memoirs, first published under the title Memoiren einer arabischen Prinzessin in 1886, at the height of Germany's imperial expansion, and on her posthumous Briefe nach der Heimat (1999) for Ruete's later life in Germany. ${ }^{42}$ Already one of the most prominent cases of transcultural migration in the late nineteenth century, attracting sensationalist press coverage in 1871 and 1885 as 'der größte Sex-Skandal in der Geschichte Sansibars', ${ }^{43}$ Ruete has recently become the subject of postcolonial interest, reflected in the new editions of her writings, and Sansibar Blues is set to enhance curiosity further. Her memoirs focus on her youth in Zanzibar and conclude with only a brief summary of her departure and marriage, her first twenty years in Germany, and her politicised visit to Zanzibar in 1885. In an attempt to rectify German Orientalist misconceptions, the memoirs give a detailed and often ethnographical account of life at the Sultan of Zanzibar's court and of nineteenth-century

\footnotetext{
$41 \quad$ See Iris Hahner-Herzog, Tippu Tip und der Elfenbeinhandel in Ost- und Zentralafrika im 19. Jahrhundert, Munich 1990.

42 Emily Ruete, geb. Prinzessin Salme von Oman und Sansibar, Leben im Sultanspalast: Memoiren aus dem 19. Jahrhundert, hg. und mit einem Nachwort von Annegret Nippa, Berlin, Vienna 2000; Emily Ruete, geb. Prinzessin Salme von Oman und Sansibar, Briefe nach der Heimat, hg. und mit einem Nachwort von Heinz Schneppen, Berlin, Bodenheim bei Mainz 1999. For an English translation of Ruete's writings see Sayyida Salme / Emily Ruete, An Arabian Princess Between Two Worlds: Memoirs, Letters Home, Sequels to the Memoirs, Syrian Customs and Usages, ed. by E. van Donzel, Leiden, New York, Cologne 1993.
} 
Zanzibari history and society, as seen from the perspective of a female member of Sultan Said's extended family. Frequently comparing Oriental and European conditions and views, and criticizing elements of both, Ruete aims at objective representation, while at the same time defending Oriental culture and Islam against German stereotypes and colonial thought. By contrast the letters, cast as letters to a female friend in Zanzibar and covering her journey to Germany and her life there into the 1880 s, offer an intimate and emotional account of the hardship of her migration and of a life torn between cultures, exacerbated by the challenge of having to make a living for herself and her three children, when her late husband's fortune was largely lost in the financial crisis of the early 1870s and due to embezzlement.

Sansibar Blues makes extensive use of Ruete's memoirs and letters, often integrating literal quotations in the first-person narrative of her fictionalised alter ego. A typical example is a passage describing the hustle and bustle in a Zanzibari palace, which epitomizes the intensity, sensuousness and lively chaos of African-Oriental life and the multilingualism and multiculturalism of Zanzibar (see pp. 46-48). The description combines elements of two equivalent passages from Ruete's memoirs, ${ }^{44}$ which Ruete herself already presents as 'Genrebilder' tailored for the European imagination of the Orient. ${ }^{45}$ Literal quotations include the opening epithet 'das bunte Treiben', the long list of Oriental, Indian and African languages spoken, the envy and jealousy ('Mißgunst und Neid') between light-skinned Arabian and dark-skinned African members of the harem, the clapping of hands to call servants, the comment that the complaint 'Es zieht' is 'unbekannt' in the heat of the Orient, ${ }^{46}$ and the linguistic comment about the Arabic word for the women's wooden sandals, which epitomizes linguistic difference by taking two seemingly very different shapes for the singular and the plural ('Kubkab', 'Kabakib’). ${ }^{47}$

At the same time the passage illustrates the transformation of such source material in the novel. Buch condenses Ruete's much more extensive and detailed descriptions into one emblematic scene and fictionalises the memoirs' biographical and ethnogaphical account by adding colour and drama, often at the expense of biographical truth. Buch's Emily, for example, claims to have done her homework in the midst of this 'babylonische Durcheinander' (p. 47), where Ruete passes repeated and critical comment on the rigorous German school system insisting that her basic schooling as a child in the palace's Koran

\footnotetext{
$43 \quad$ Frederick Cooper, Plantation Slavery on the East Coast of Africa (New Haven 1977, p. 116), cited in German in Buch, p. 176, based on the editor's notes in Ruete's Briefe nach der Heimat, p. 174.

44 Ruete, Leben im Sultanspalast, pp. 31-33, 35.

45 Ibid., p. 35.

$46 \quad$ Ibid., p. 25.

47 Ibid., p. 35.
} 
classes had not included homework. ${ }^{48}$ Where Ruete tells us that the palace's chefs frequently boxed their assistants' ears because they did not work fast enough, ${ }^{49}$ the kitchen helpers in Buch's adaptation suffer the same penalty 'wenn, was häufig vorkam, ein Küchenjunge aus dem Topf naschte oder ein Küchenmädchen einen Teller zerbrach' (p. 48). And the end of the passage in Sansibar Blues suggests that Emily's mother may have died early because she was poisoned, while the memoirs state quite clearly that she died from cholera (p 48). ${ }^{50}$ Condensation, fictionalisation and dramatisation equally affect the account of Ruete's sensational relationship with her later husband and her involvement in a failed coup against her brother Majid, the ruling Sultan at the time, where poetic licence leads to misrepresentation of potentially significant detail. To give one last example, Buch's Emily travels from Aden to Germany via Cape Town, because 'Der Suezkanal war damals noch nicht eröffnet' (p. 153), whereas the historical Ruete family clearly took the traditional Arabian route via the Red Sea and Egypt. ${ }^{51}$ In this case poetic license reinforces Eurocentric notions of Orient backwardness instead of using Ruete's story to raise awareness of precolonial history and non-European infrastructure.

There is thus tension throughout the Ruete strand between the condensed literary retelling of her life and the reworking of this material for a highly dramatic and entertaining account of this transcultural biography. At times this fictionalised accout resonates more with the patterns of Orientalist adventure stories (such as the tropes from Arabian Nights that informed the press coverage of her life at the time) and with the contemporary reader's supposed expectations than with historical and biographical truth. Condensation is matched in other parts by fictional extensions, including, for example, a dialogue between Ruete and Bismarck that references today's popular knowledge about Germany's imperial ambitions (pp. 165-68). The liberties that Buch takes are particularly obvious in the style of his narrative. Ruete's alter ego in Sansibar Blues uses expressions and colloquialisms from today's usage as well as an often ironic and even flippant tone, which is a world away from the ethnographic objectivism and restraint of Ruete's memoirs and the intimate suffering and self-reflection of her letters. To give just a few examples, the historical Ruete would certainly not have called the inhabitants of Aden 'schwarze, weiße und braune Teufel' (p. 151), suggested that Carl Peters had 'mit getürkten [sic] Verträgen den dortigen Häuptlingen Land abgeluchst' (p. 168), or introduced her cross-cultural romance (and its policital implications) with the following sentence: "“Wir gehen gleich in medias res - mit diesen Worten hat mein

See ibid., p. 72.

Ibid., p. 32.

See ibid., p. 199. 
späterer Mann mich in einer Vollmondnacht auf Sansibar entjungfert.' (p. 165) The anachronisms in this sometimes laboured humour are made explicit, when Buch's Emily discusses Freud (p. 46) and notes the 'pornographisch[e] Film hinter den niedrigen Stirnen' of white German works in Hamburg staring at her Oriental appearance, which is 'ein Anachronismus, ich weiß, denn damals gab es weder Pornofilme noch Sexshops' (p. 154). At points such as these it is no longer clear whether it is the character speaking or her author.

Buch's poetics of transcultural memory are thus based on radical modernization of his transcultural source rather than historical reconstruction or literary mimicry. This could be seen as yet another appropriation of an African-Oriental voice, and the rather far-fetched reference to the African-American blues in the novel's title raises smiliar questions. The artificiality of this transcultural voice, however, is quite obvious and deliberate, and the metareflexive narrative demonstrates full awareness of the free use made of historical material, defying expectations of naïve realism or exotic 'authenticity'. For example, the account given of Ruete's life is put in perspective as no more than one potential version of her life: 'So ähnlich könnte es gewesen sein' (p. 59), 'jede Biographie ist eine Heiligenlegende, die nie die ganze Wahrheit wiedergibt' (p. 176). The illusion of a consistent first-person narrative is also broken at significant points, including fictional Emily's account of her own death (p. 175) and a passage where the narrative slips into the third person to distance itself from Ruete in ideological terms: "Da ich als Araberin selbst eine Semitin bin, kann von Antisemitismus keine Rede sein", fügt die Verfasserin an dieser Stelle hinzu.' (p. 165) ${ }^{52}$

Another element of postmodern metafiction ${ }^{53}$ is the extensive use of intertextual references that link the narrative to the history of Orientalist discourses in German culture and literature, most notably Mozart's Entführung aus dem Serail, to which the Ruete strand owes its subtitle (p. 41), Goethe's West-Östlicher Diwan (p. 55), Karl May's popular orientalist novels, such as Durch das Land der Skipetaren (p. 45), and the Arabian Nights (p. 157 and passim), already referenced in Ruete's memoirs. ${ }^{54}$ Moreover, anachronistic blending of nineteenth-century experience with twentyfirst-century knowledge and attitudes defamiliarizes the narrative throughout; and the novel's narrative style is marked by

\footnotetext{
$51 \quad$ See Ruete, Briefe nach der Heimat, pp. 11-12.

52 Irritatingly condensation here translates into omission of Ruethe's differentiation 'so kann bei mir von Antisemitismus im europäischen Sinne keine Rede sein' (Briefe nach der Heimat, p. 131), which suggests a more complex discussion.

53 See Patricia Waugh, Metafiction: The Theory and Practice of Self-Conscious Fiction, London 1984.

$54 \quad$ See Ruete, Leben im Sultanspalast, p. 180.
} 
metafiction and hybridisation of genres, ${ }^{55}$ in particular a blend of narrative and essayism. One example is the following passage, in which the first-person character-narrator supposedly summarizes her involvement in German colonial politics, amusingly slipping into quite implausible anachronistic historiography:

[...] Bismarck versuchte, den Erbanspruch meines Sohnes Said auf den demnächst frei werdenden Thron von Sansibar geltend zu machen. Ohne mein Zutun wurde ich so zum Bauer auf dem Schachbrett der Diplomatie und zum Instrument einer imperialistischen Strategie, die als Kanonenbootpolitik in die Geschichtsbücher eingegangen ist. (pp. 16869)

Another example of such slippage is the opening 'prologue' of the Ruete strand, which has Ruete herself comment on three photographs taken of her at three stages of her life in Germany (all printed in the 1999 edition of her letters), ${ }^{56}$ only the first of which is included in novel's picture gallery. When the first-person narrator uses these pictures from the cultural archive to introduce Zanzibari history and her own life, commenting, for example, on the location of her father's portrait in today's museum in Zanzibar (pp. 41-45), Ruete's voice becomes a rather transparent mask of the author who works his way into his historical material.

Buch's novel is clearly less interested in historical or cultural authenticity than in raising curiosity about colonial history and transcultural experience by providing intellectually informed entertainment. This can also be seen in the Tippu Tip strand of Sansibar Blues, where Buch draws on Heinrich Brode's biography of 1905, 'nach seinen [i.e. Tippu Tip's] eigenen Angaben dargestellt', rather than on Brode's principal source, Hamed bin Mohammed's autobiography, published in Brode's German translation in 1902/03. ${ }^{57}$ Using Brode's quotations from and comments on Hamed's autobiography for self-reflexive heteroglossia, ${ }^{58}$ the Tippu Tip strand shifts between first and third person narration, increasingly blurring the distinction between Tippu Tip's and Brode's voices, as an intervening third person narrator ${ }^{59}$ attributes the account to 'Tippu Tip alias Dr. Brode' (p.

\footnotetext{
55 On the latter see Birgit Neumann and Ansgar Nünning, 'Einleitung: Probleme, Aufgaben und Perspektiven der Gattungstheorie und Gattungsgeschichte', in Gattungstheorie und Gattungsgeschichte, ed. by Marion Gymnich, B. Neumann and A. Nünning (Trier 2007), pp. 1-28 (pp. 13-14).

56 See Ruete, Briefe aus der Heimat.

57 Heinrich Brode, Tippu Tip: Lebensbild eines zentralafrikanischen Despoten: Nach seinen eigenen Angaben dargestellt, Berlin 1905; [Hamed bin Mohammed], 'Autobiographie des Arabers Schech Hamed bin Muhammed el Murjebi, genannt Tippu Tip: Transcribirt und übersetzt von Dr. H[einrich] Brode', in Mittheilungen des Seminars für Orientalische Sprachen zu Berlin, 3. Abt.: Afrikanische Studien, 1902, pp. 175-277, and 1903, pp. 1-55.

58 See Mikhail M. Bachtin, 'Discourse in the Novel', in: The Dialogic Imagination: Four Essays, ed. by Michael Holquist, transl. Caryl Emerson and M. Holquist (Austin/Texas 1981), pp. 259-422 (p. 263).

59 On one occasion this third person narrator, the author's alter ego, also uses the first person (p. 104), which is otherwise reserved for Tippu Tip.
} 
$195,203)$, in an ironic reference to the German mediation of this African-Arabian voice. On one occasion the novel even attributes Tippu Tip's thought to Brode, ${ }^{60}$ while at other points Buch invents comments for both voices for which there is no evidence in his sources, or questions the reliability of his source. This discursive approach at narration is another aspect of postmodern metafiction in Sansibar Blues and gives readers the sense that they are (re-) reading Buch's source material with him.

As in the Ruete strand, however, the use of poetic licence becomes problematic where it replicates European stereotypes about Africa or produces clichéd images of the nonEuropean Other. One such example is the episode where Tippu Tip is joined by Henry Morton Stanley, who boasts about his automatic weapons in order to demonstrate 'die Überlegenheit westlicher Waffentechnik' (p. 182). As in the source texts, Buch's Tippu Tip is clearly interested in this innovation, ${ }^{61}$ but the novel also invents a comment which surprisingly portrays Brode (and potentially Tippu Tip) as arms specialists: 'Überflüssig zu sagen, fügt Dr. Brode hinzu, daß es sich um eine Winchester 66 und einen 45er Colt handelte' (p. 182). Indeed, Buch's Tippu Tip is presented very much as a gunslinger, who treats interior Africa as his very own Western frontier and uses ruthless force to establish his 'innerafrikanische Reich' (p. 196) in Eastern Congo. ${ }^{62}$ Both Brode and Buch present Tippu Tip as a figure of power who anticipates European exploration and colonial rule within the context of African-Arabian culture and therefore puts Eurocentric accounts of African history in perspective. But Brode portrays him as an educated personality of equal standing with imperial rulers and explorers such as Livingstone, Cameron, Stanley, or Schnitzer, avoiding colonialist and exoticist clichés, while Buch uses stereotypical imagery to cast him as a ruthless adventurer, who may invite sympathy for his picaresque traits, but certainly not the respect that Brode suggests. This can also be seen in the way Buch uses Hamed's own

\footnotetext{
60 For example, Buch's Dr Brode notes that in Utetera 'die Felder so fruchtbar waren wie die Weiber schön' (p. 196), where Brode's biography has a quotation from Tippu Tip stating 'denn die Schensis [i.e. heathen Africans, D.G.] jener Gegend sind gutherzig, die Weiber sind schön und das Land ist fruchtbar’ (Brode, p. 86).

61 See Hamed bin Mohammed, p. 260f.; Brode, p. 71.

62 For example, when Tippu Tip and his men return fire after being attacked by the army of Ugalla, Buch's Tippu Tip shoots first the local sultan's wife and then the fleeing sultan himself (p. 92), while in Brode's account there is no mention of the sultan's wife and it is not Tippu Tip who shoots the sultan (Brode, p. 39). In the episode in which Tippu Tip becomes the sultan of Utetera by cleverly exploiting local credulity and the ruling sultan's apparently voluntary abdication, Buch has him shooting 'einen lästigen Mitwisser' (p. 101) to secure his power, whereas Brode emphasizes the peaceful nature of the coups despite also voicing some doubt about Tippu Tip's account (Brode, p. 58f.; see Hamed bin Mohammed, pp. 247-48). In another armed conflict 'Tippu Tips Maxim-Haubitze' supports 'Stanleys Repertiergewehr' (p. 191) in fighting off an attack on the Congo river, where both actually used simple shotguns ('Schrot'; Hamed bin Mohammed, p. 264). Even Buch's representation of Tippu Tip's conflict with his father about the first expedition outside parental control includes the shooting of Tippu Tip's gun for melodramatic effect (p. 76), a motif not suggested by Buch's sources.
} 
references to African slavery and cannibalism prominently and for grotesque effect (e.g. p. 99, 102), which Brode is keen to tone down. ${ }^{63}$ At times the world of grotesque violence and chaos in Buch's interior Africa is reminiscent of the phantastic and equally grotesque Congo of Urs Widmer's novel Im Kongo (1996). ${ }^{64}$ Both novels transform exotic adventure into humorous meta-critique of colonialist tropes and discourses, but Im Kongo is deliberately set on the stage of the European imagination and has little to do with real Africa, ${ }^{65}$ whereas Sansibar Blues is surprisingly candid in tailoring its transcultural source to European expectations rather than exploring otherness in its own right.

In its representation of Tippu Tip's life Sansibar Blues employs a similar approach of selective fictionalization, condensation and dramatisation as in the Ruete strand. The narrative broadly follows Brode - from his historical introduction to the concluding 'INSCHALLAH' (p. 216), ${ }^{66}$ both of which Buch attributes to Tippu Tip - and includes some almost literal adaptations of Brode's and Hamed's texts. ${ }^{67}$ Examples of dramatic condensation include eighteen year old Tippu Tip's discussion with his father about his first independent expedition, which modern Freudian notions turn into a melodramatic generational conflict (pp. 76-78), for which there is no place in the historical Hamed's culture, although his own account also marks his early sense of independence. ${ }^{68}$ In a corresponding later episode Buch combines Tippu Tip's reunion with his old father in Tabora with his reunion with his own first-born sun Sef, now himself eighteen years old, in one emotional family scene, marked by fourteen days of celebration (p. 197), while these were actually two separate incidents,

63 This is the clearest evidence that Buch may also have consulted Hamed bin Mohammed's autobiography. These themes of slavery and cannibalism resonate uneasily with European stereotypes about pre-colonial Africa, but also reflect Hamed's openness about his use of violence and his disgust at the perceived lack of civilization amongst 'heathen' Africans. In his account about one of his many victories against hostile Africans he reports, for example, 'in ihren Ortschaften legten wir Feuer, und von ihren Weibern erbeuteten wir etwa 400 Stück' (Hamed bin Mohammed, p. 232); on another occasion he laments his failure to stop cannibalism: 'Und die Schenzis frassen sich untereinander auf, zwei Leute pflegten einen ganzen Menschen zu fressen.' (Hamed bin Mohammed, p. 250) Brode tries to put such instances of stereotypical African primitivism in cultural and historical perspective and uses less outspoken language. Urs Widmer, Im Kongo (Zurich 1996). The similarity in style is particularly obvious where the reality of central Africa becomes as illusive in Sansibar Blues as it is in Im Kongo; see for example Tippu Tip's comment: 'Schon damals hegte ich den Verdacht, die Wabembe, und die Watembe seien ein und dasselbe Volk [...].' (p. 80)

65 See Göttsche, 'Zwischen Exotismus und Postkolonialismus', pp. 212-19.

66 See Brode, p. 165.

67 One example is the beginning of the episode in which Tippu Tip fraudulently claims to be Sultan Kasongo Ruschie's grandson, using information about the sultan's missing daughters as well as Kasongo's naivité to seize power in the Manyema region of Eastern Congo. The opening passage (pp. 9697) is taken almost literally from Brode's account (p. 53), which again quotes Hamed's autobiography (pp. 237-239). Other examples are the list of points in Tippu Tip's contract with Henry Morton Stanley (pp. 184-185; see Brode, pp. 74-75) and the mix of Stanley's and Brode's descriptions of Tippu Tip's appearance (p. 183; see Brode, pp. 10 and 72), although Buch may also have used Stanley's own publications.

68 See Brode, p. 10-12; Hamed bin Mohammed, pp. 176-77. 
followed shortly by the father's death, and the reunion with Tippu Tip's father included a step-brother rather than his son. ${ }^{69}$

This is also a small example of how Sansibar Blues reduces the complexity of its biographical source material. For example, Buch reverses the chronology of events by letting the British consul in Zanzibar, Sir John Kirk, ask Tippu Tip to look for Livingstone (p. 88), whom he then finds in Urungu (p. 90), where the historical Tippu Tip's first encounter with Livingstone actually predates this particular return to Zanzibar, where Tippu Tip handed Kirk a letter from Livingstone. ${ }^{70}$ Together with Tippu Tip's supposed impersonation of Stanley greeting Livingstone with the latter's famous words 'DR. LIVINGSTONE, I PRESUME' (p. 90) - the reversal supposedly yields a more poignant episode. In similar fashion Tippu Tip's meeting with Sultan Bargash in Sansibar Blues (p. 201-03) compounds elements of two meetings ${ }^{71}$ about the possibility of counter-acting German and Belgian colonial expansion by establishing Zanzibari territorial rule in East and central Africa, and it reassigns voices across the cultural divide by making both this proposal (which Brode attributes it to the British consul) and also critical assessment of the far-reaching impact of Bargash's decision not to take military and political control of Zanzibar's African hinterland to Tippu Tip himself (rather than to Brode). In this case poetic license suggests that the culture divides between Europeans, Africans and Arabs was less significant than the fact that the characters in question were all players in the colonial game for power in Africa, but there is also a tendency in Buch's narrative to filter African-Arabian otherness through European eyes. Examples are Tippu Tip's memory in Sansibar Blues of uttering Stanley's famous greeting to Livingstone, although he immediately adds 'Nein, so kann es nicht gewesen sein' (p. 90), or his description of the ingenious military device that enabled him to storm the seemingly impenetrable fortifications of an enemy town, as a 'Holzpferd [...] mit Rädern' (p. 199) in a clear reference to the Trojan horse and thus to Greek myth, where Brode simply quotes Hamed's own account, which describes a wooden 'Gerüst' on wheels, enabling the attackers to stand higher than the town walls. ${ }^{72}$

The narrative itself focuses on some of the episodic highlights of Hamed's life, such as his dealings with the famous European explorers of the time and his most salient and grotesque adventures. Buch is obviously less interested than Brode in Tippu Tip's achievements in central African politics, his pivotal role in the Zanzibari-European rivalry and his later involvement with emerging Belgian rule in Congo. Unlike the Ruete strand the Tippu

See Brode, pp. 92-93, 96; Hamed bin Mohammed, p. 277.

See Brode, p. 24, 34; Hamed bin Mohammed, p. 195-96, 205.

See Brode, pp. 104-05, 119; Hamed bin Mohammed, p. 33. 
Tip chapters, however, do not radically modernize this transcultural voice. The historical Hamed bin Mohammed remains illusive in the Tippu Tip strand of Sansibar Blues, as the narrative diverts cross-cultural curiosity into a pastiche of exotic adventure.

III.

Staging the voices of Emily Ruete and Tippu Tip as witnesses to the colonial era, Buch's transcultural poetics in Sansibar Blues echo the fascination in contemporary television with documentary fictions ('Dokudrama'), discussed by Struck, ${ }^{73}$ except that Buch's metareflexive style disrupts the deceptive realism of such cinematic reenactment of the past. In its use of transcultural voices Sansibar Blues, despite its problematic obsession with European clichés, illustrates growing interest in the African experience of colonialism, but by implication it also highlights the very limited presence and prominence of African postcolonial memory proper in German cultural debate. ${ }^{74}$

In terms of the place of postcolonial memory in contemporary Germany's memorial culture of memory, it is worth noting that the highly entertaining and grotesque potpourri of voices in Sansibar Blues also includes unexpected cross-referencing of colonialism and National Socialism in its second strand, the fictional East German diplomat's account of his youth as a servant's son in the Duke of Mecklenburg-Schwerin's palace during the 1930s and 1940s. The novel characterizes the Duke as an unwavering colonial revisionist and a reactionary opponent to Hitler's regime, who entertains the young boy with his adventures in Africa, placing exoticist fascination with Africa at the centre of the adolescent's imagination. The boy's exclusion from the Hitler Youth due to the Communist affiliations of his father as well as contextual references to the violent history of the Third Reich - from SA marches and anti-Semitic pogroms to the Russian campaign and the battle of El Alamein (p. 18) - mark such colonial exoticism as imaginary escape from the threats of Nazi rule. ${ }^{75}$ In a radical break with post-war Marxist understanding of colonial imperialism as historical preparation for Hitler's regime ${ }^{76}$ Buch thus places colonialism in opposition to the Third Reich.

\footnotetext{
$72 \quad$ Brode, p. 96; Hamed bin Mohammed, p. 8.

73 See Wolfgang Struck, 'Reenacting Colonialism: Germany and Its Former Colonies in Recent TV Productions', in German Colonialism, Visual Culture, and Modern Memory, ed. by Volker M. Langbehn, New York, London 2010, pp. 260-277.

74 See Dirk Göttsche, 'Recollection and Intervention: Memory of German Colonialism in Contemporary African Migrants' Writing', in African and Asian Responses to German Colonialism, ed. by Nina A. Berman, Klaus Mühlhahn and Patrice Nganang (forthcoming). As one of the novel's many literary references, this motif is probably a tribute to Alfred Andersch's acclaimed novel Sansibar oder der letzte Grund (1957), in which the African island plays a similar role. 
This unusual turn sets the scene for the novel's satire of GDR politics and Socialist internationalism. As the aptly named Hans Dampf embraces post-war Marxist-Leninist ideology, completes his university study with a $\mathrm{PhD}$ on the Maji Maji uprising in German East Africa and becomes the German Democratic Republic's first ambassador to postindependence Zanzibar, early exoticist fascination unwittingly makes him a tool in Cold War power politics, and Eastern European support for African decolonisation ironically turns out to be just another mask of neo-colonialism. The novel's transcultural theme, however, complicates this assessment. The boy whose imagination was trained by colonial revisionism, eventually marries the last ruling Sultan of Zanzibar's niece and adopts her two sons; and the colonial theme extends to critical memory of East Germany, when his sons find their sporting careers checked by the GDR's mode of 'Apartheid' (p. 148), being excluded from national competition for unacknowledged racial reasons. Hans Dampf's path from colonial fascination through implication in neo-colonialism to postcolonial transculturalism thus illustrates both colonial legacies and the ability to overcome them, and his eventual diplomatic involvement in Namibia's independence in 1990 (p. 148) balances his grotesque role as uneasy missionary of GDR internationalism. Such cross-mapping of the two memory themes echoes similar memory discourses in contemporary Black German and African diasporic writing and reflects the 'multidirectional' potential of collective memory. ${ }^{77}$

At the same time, the novel's second strand bridges the historical gap between the colonial transculturalism represented by Emily Ruete and Tippu Tipp, and contemporary postcolonial multiculturalism, epitomized by Hans Dampf's transcultural family. Crosscultural experience continues to be a central theme both in German mainstream literature about contemporary Africa and in the German literature of the African migration. ${ }^{78}$ If anything, literary interest in German and African cross-cultural experience has grown over the past fifteen years, and the increased multiculturalism of contemporary society along with heightened awareness of transcultural lives need to be seen as part of the same historical situation that also produces revisionist agendas and the popular visions of colonial Heimat discussed at the outset of this article. Buch's Sansibar Blues and Trojanow's Der Weltensammler succeed in using the fascination of colonial adventure and exotic crosscultural experience to expose colonialist and exoticist discourses, and foster curiosity about

\footnotetext{
77 See Michael Rothberg, Multicirectional Memory: Remembering the Holocaust in the Age of Decolonization, Stanford/CA 2009.

78 See Dirk Göttsche, 'Colonial Legacies and Cross-Cultural Experience: The African Voice in Contemporary German Literature', Edinburgh German Yearbook, 1 (2007), 160-176; Dirk Göttsche, 'Cross-Cultural Self-Assertion and Cultural Politics: African Migrants' Writing in German Since the Late 1990s', German Life and Letters, 63 (2010), 54-70; Sara Lennox, 'Postcolonial Literature in Germany', in Cambridge History of Postcolonial Literature, ed. Ato Quayson, Cambridge (forthcoming).
} 
the experience and perspective of non-European others through transcultural and selfreflexive multiperspectivism. The question remains, however, to what extent such postcolonial poetics justify the radical modernization and rewriting of transcultural voices in Sansibar Blues, which tends to collapes the difference between 'das Fremde' and 'das Eigene' rather than explore their dialectic interaction and promote a dynamic of cross-cultural dialogue and historical understanding. In a sense the reader has to turn to Emily Ruete's and Hamed bin Mohammed's own accounts to fully develop the productive dynamic of 'wechselseitig wahrgenommene Andersheit'. 79 